\title{
The Impact of Reflective Writing on Writing Achievement, Vocabulary Achievement and Critical Thinking of Intermediate EFL Learners
}

\author{
Narges Sadat Laqaei \\ Department of English Language, Shahr-e-Qods Science and Research Branch, Islamic Azad \\ University, Tehran, Iran \\ E-mail: laghaee65@yahoo.com
}

Behdokht Mall-Amiri (Corresponding author)

Department of English Language, Shahr-e-Qods Branch, Islamic Azad

University, Tehran, Iran

E-mail: Beh.malamiri@iauctb.ac.ir

Received: Feb. 22, 2015 Accepted: July 18, 2015 Published: August 20, 2015

doi:10.5296/jse.v5i3.7964

URL: http://dx.doi.org/10.5296/jse.v5i3.7964

\begin{abstract}
The present study investigated the effectiveness of a rather newly- developed method in language teaching that was reflective writing in improving EFL learners' writing achievement, vocabulary achievement and critical thinking. To fulfill the purpose of the study, first 60 participants from among 100 intermediate learners studying at Tehran University of Medical Sciences were chosen by means of administrating Preliminary English Test (PET), Vocabulary Test, and Critical Thinking Questionnaire developed by Honey(2000),. Then through administrating the writing section of the standard preliminary English test (PET), Vocabulary Test, and Critical Thinking Questionnaire developed by Honey (2000), 60 out of 90 remaining learners were chosen to serve as the participants of the study. Two groups, a control group and an experimental group, were formed. The experimental group was provided with reflective writing instructions, while the control group received the routine writing practices. To see if the independent variable had significant effects on writing achievement, vocabulary achievement, and critical thinking, a Multivariate Analysis of Variance test was run the results of which revealed that the treatment significantly improved vocabulary, writing and critical thinking of the learners.
\end{abstract}

Keywords: Critical thinking, Vocabulary, Writing, Reflective writing 


\section{Introduction}

An increasing number of courses require students to write reflectively. Reflective writing may be an occasional requirement or it may be core feature of most or all assignments. Reflective writing involves a description of an issue or experience as well as an exploration of one's response to it. This reflection occurs within the framework of what you have already learned so that new insights can be drawn from the experience and, if necessary, changes may occur in your attitude and behavior (Branch \& Paranjape, 2002, p. 1185).

Reflective writing is a process where you can learn from your experiences. It can help make you become more aware of assumptions and preconceived ideas. It also helps you to translate the abstract ideas in your study into the practice of your profession. There are a number of parts to a piece of reflective writing:

The first part is the introduction. Introduction should focus on the main point of the writing piece, that is, the change or variation in thinking and/or behavior that occurred as a result of the experience.

The second part is description. Before analyzing its significance, the issue or experience is described. Also, a description of your feelings and reactions to it may be included and any relevant observations. Note that it is appropriate to write in the first person, using "I" or "we" when describing the experience.

The third part is analysis. In this part connections are made between the issue or experience and your previous learning, experience and understandings. Significant factors underlying the experience may be highlighted showing why they are important for a new understanding. If relating this back to the academic literature, then these should be cited and referenced in the writing.

The last part is conclusion. This outlines the changes in understanding and/or behavior as a result of the experience, explaining the implications for this in one's professional practice (Branch \& Paranjape, 2002, p. 1185).

There are some kinds of check list for reflective writing. The following is one of them.

- Described the issue or experience upon which you are reflecting?

- Described your own reactions to the experience?

- Made connections between this experience and previous learning and experience?

- Analyzed and highlighted the significant factors in the situation?

- Outlined how the issue or experience changed your understanding and/or behavior?

- Explained the implications of this new understanding for your professional practice?

- Written an introduction, body and conclusion?

- Checked punctuation and spelling? (Branch \& Paranjape, 2002, p. 1185). 
According to Branch and Paranjape (2002) reflective writing is writing which involves '... consideration of the larger context, the meaning, and the implications of an experience or action'(p. 1185). It is evidence of reflective thinking. In an academic context, reflective thinking usually involves:

- Looking back to something (often an event, i.e. something that happened, but it could also be an idea or object).

- Analyzing the event or idea (thinking in depth and from different perspectives, and trying to explain, often with reference to a model or theory from our subject).

- Thinking carefully about what the event or idea means for you and your ongoing progress as a learner and/or practicing professional (Branch \& Paranjape, 2002, p. 1185).

In addition reflective writing is more personal than other kinds of academic writing. We all think reflectively in everyday life, of course, but perhaps not to the same depth as that expected in good reflective writing at university level.

Most language teachers have experienced the disappointment of putting great amount of energy in their students' writing and getting very little results. EFL/ESL writing has always been considered an important skill in teaching and learning (Branch \& paranjape, 2002, p. 1185).

One of the main objectives of writing instruction is to enable the students write well. According to Richards and Renanya (2002, as cited in layeghi 2011) "there is no doubt that writing is the most difficult skill for second language learners to master" (p. 33). Yet it is generally construed from the published articles that EFL learners do not write as well as we think they should. ( e.g., Hillocks 1986; Ping, 2000; Rijaarsdam et a., 2005). The writing is not well organized, and full of grammatical or spelling mistakes. The reason for inability to write well enough to meet teachers' expectations are many and varied. (layeghi, 2011).

However according to Smit (1911), one of the most obvious reasons that students do not write well is that they do not receive a great deal of instructions. Instructions that should make learners generate some content, put forth assumptions, evidence, and arguments that they can then defend and from which they can draw conclusions (Kurland, 2000, as cited in NorayAlagozlu 2007). Perhaps, one of the reasons for this problem can be traced back to the inability of the students to analyze, evaluate and organize their thoughts and this, in turn, seems to be directly related to the lack of critical thinking in them.

Many adults are not able to live, work, and function effectively in this highly technical world. The problem is how to develop the skills, which are needed to be productive and informed members of this world, which changes continually, invent new ways of solving problems, connect new knowledge to the information they already have and apply their knowledge in new situations. In short, individuals must develop critical thinking skills, which are the most important goals in education. A person who thinks critically can ask appropriate questions, 
gather relevant information, efficiency and creatively sort through this information, reason logically from this information, and come to reliable and trust worthy conclusions about the world that enable him to live and act successfully in it (Center for critical thinking,1996a).

A person who practices critical thinking (CT) can achieve a productive, successful, ethical, happy, satisfying and fulfilling life (Ellis, 2003).

Critical thinking should be taken into account to teach learners how to challenge various viewpoints. Halpern (1997) asserts that critical thinking is the "use of cognitive skills of strategies that increase the probability of a desirable outcome. It is used to describe thinking that is purposeful, reasoned and goal directed (P.4). She cites several other definitions from the cognitive perspective: "critical thinking is the formation of logical inferences" (p. 4); it is the development of cohesive and logical reasoning and patterns; it is careful and deliberate determination of whether to accept, reject or suspend judgment; it is a mental activity useful for a particular cognitive task (Halpern1997, p.4, as cited in Shangarffam \& Mamipour, 2011).

Critical thinking is considered to be central to higher education or an essential goal of teaching ( Kuhan, 1999; as cited in Gorgian, Pazhakh \& Parang, 2012). Many Iranian researchers have asserted the influential role of critical thinking in students' academic achievement (e.g. Birjandi \& Bagherkazemi, 2010; Fahim, Bagherkazemi \& Alemi, 2010). Other researchers have asserted the influential role of critical thinking in different contexts (McCutchen, Apperson, Hanson, \& Wynn, 1992; Yeh \& Wu, 1992 as cited in Dabaghi, Zabihi, \& Rezazade, 2012).

Schaferman (1991) conducted researches on the effective methods of applying critical thinking to language classes. These attempts led to the emergence of critical thinking pedagogy or critical thinking which aims at enabling learners to evaluate what they read, write or hear, pose questions and seek for reasons and have sound judgment (Gorgian, Pazhakh, \& Parang, 2012) in order to improve learners' writing through critical thinking pedagogy.

A major point concerning the pedagogy of critical thinking is that the emphasis is on the learner rather than the teacher and a main significance to the efficiency of critical thinking is the personal features of the learners that the teachers should take those personal differences into accounts (Marashi, 2012).

Vocabulary is an inseparable part of any language learning process. It would be impossible to learn a language without vocabulary. The important role of vocabulary has been emphasized in all different methods in language teaching. River (1981) says "vocabulary cannot be taught. It can be presented, explained, included in all kinds of activities, but it must be learned by individuals" (p...28). She further states that, "as language teachers, we must arouse interest in words, a certain excitement in personal development in this area" (p.29). She suggests that language teaching must help their students by giving them ideas on how to learn vocabulary and some guidance on what to learn. 
Vocabulary as a major component of language learning has been the object of numerous studies each of which has its own contribution to the field. Laufer (1997) states that vocabulary learning is at the heart of language learning and language use. In fact, it is what makes the essence of a language. Without vocabularies speakers cannot convey meaning and communicate with each other in a particular language.

Vocabulary is of high importance in the area of second/foreign language learning and teaching. It is a fact that there is no language without words and words are the buildingblocks of a language (Thornbury, 2002). Decarrico (2001, p.285) points out that "vocabulary learning is central to language acquisitions whether it is a second, or a foreign language, even in a learners mother tongue, there is an incessant learning of new words and new meanings for old words" (Decarrico, J. s. 2001). But the acquisition of a large number of vocabulary items may be considered as of the most difficult aspects of learning a second language for most L2 learners (Meara, 1980, p. 221; Read 2000, p.1).

\section{Review of Literature}

\section{1 critical thinking}

Over the past twenty years critical thinking has moved from a small corner of the stage in philosophy and the social sciences to front and center. Higher education writers agree that critical thinking should be included in the undergraduate curriculum. However, there seems to be little agreement on exactly critical thinking is (Allen, Rubenfield, \& Scheffer, 2004).

A person who thinks critically employs the scientific method for understanding the ordinary world. This is true because critical thinking mimics the well- known method of scientific investigation: a question is identified, a hypothesis is formulated, relevant data are gathered, the hypothesis is logically tested and evaluated, and reliable conclusions are drawn from the result(Stapleton,2002; Angeli \& Valanides, 2009). All of the skills of scientific investigations are matched by critical thinking, which is therefore nothing more than scientific method used in everyday life. Wade(1995) identifies eight characteristics of critical thinkers: critical thinkers involve in asking questions, defining a problem, examining evidence, analyzing assumptions and biases, avoiding emotional reasoning, avoiding oversimplification, considering other interpretations, and tolerating ambiguity. Dealing with ambiguity is also seen by Strohm and Baukus (1995) as an essential part of critical thinking, "Ambiguity and doubt serve a criticalthinking function and are a necessary and even a productive part of the process" (p.56) Peak (1997), Mishoe and Welch (2002), and Facione (2007) point out critical thinkers have got different attributes which makes no difference what definition you use for critical thinking. These features help us distinguish them from uncritical thinkers. Here are some of those characteristics of a critical thinker:

- $\quad$ asks relevant questions to the issue

- $\quad$ assesses arguments which are made

- $\quad$ admits a lack of understanding 
- has sense of curiosity

- analyses the interpretations and claims made

- $\quad$ analyses the problems

- $\quad$ is eager on finding new solutions

- $\quad$ is a careful listener and is able to give appropriate feedback

- does not jump to conclusions before all the facts have been collected

- looks for proof

- $\quad$ rejects incorrect or irrelevant information

- compares beliefs and opinions with facts that come against them

- formulates the central ideas that are involved

Critical thinking is based on reflective thinking that is focused on interpreting, analyzing, critiquing, synthesizing, and evaluating information, arguments and experiences with a set of reflective attitudes, skills, and abilities to guide thoughts, beliefs, and actions (Ruggiero, 1989).

\subsection{Vocabulary}

"If language structures make up the skeleton of language, then it is vocabulary that provides the vital organs." (Harmer 1993: 153)

Vocabulary functions as a cornerstone without which any language could not exist. Speaking would be meaningless and perhaps impossible having only structure without vocabulary. The word "vocabulary" generally represents a summary of words or their combinations in a particular language. However, we should bear in mind, as Ur (2000: 60) remarked, that one item of vocabulary can consist of more than one word. E.g. 'post-office' consists of two words and still expresses one idea.

Vocabulary teaching is one of the most important components of any language class. The main reason is the fact that it is a medium, which carries meaning; learning to understand and express the meaning is what counts in learning languages. There has been increased focus on teaching vocabulary recently, partly as a result of "the development of new approaches to language teaching, which are much more 'word-centered'." (Thornbury 2004: vi)

\subsection{Writing}

Bye and large, writing has been considered as a support skill which was previously done to reinforce the grammar acquisition, support the memorization of language structures and emphasize, lately, on even oral proficiency as in grammar- translation, audio lingual and communicative methods respectively(Homstad \& Thorston ,1994). "A student's writing is not only used to evaluate her/his English proficiency, but also to assess her/his understanding of 


\section{Macrothink}

other subjects such as social studies, law, economics, and physical and natural sciences. Writing is also considered an important part of almost all university level courses" (Rezaei \& Lovorn, 2010, p.2).

According to Zemelman (1998) "Writing is, in fact, one of the best tools for learning any material because it activates thinking" (p.63). Since writing is viewed this way by many in the field of education, it should be used in a way that will provide the maximum contribution to learning and student achievement.

\subsection{Reflective writing}

"Reflection is indicative of deep learning, and where teaching and learning activities such as reflection are missing... only surface learning can result." (Biggs 1999 in King 2002).

Reflective writing tasks are given to students to help students learn through reflection, precisely because of the established link between reflection and deeper learning. As well as facilitating learning and monitoring learning, the intention is to produce graduates who have acquired the habit of reflection as a means of continuing to learn and grow in their professions. Reflection can lead to:

- Personal growth

- Professional growth

- Meaningful change.

"Reflection leads to growth of the individual - morally, personally, psychologically, and emotionally, as well as cognitively". (Branch \& Paranjape, 2002, p. 1187). A great deal of your time will be spent thinking; thinking about what people have said, what you have read, what you yourself are thinking and how your thinking has changed. It is generally believed that the thinking process involves two aspects: reflective thinking and critical thinking. They are not separate processes; rather, they are closely connected (Brookfield 1987).

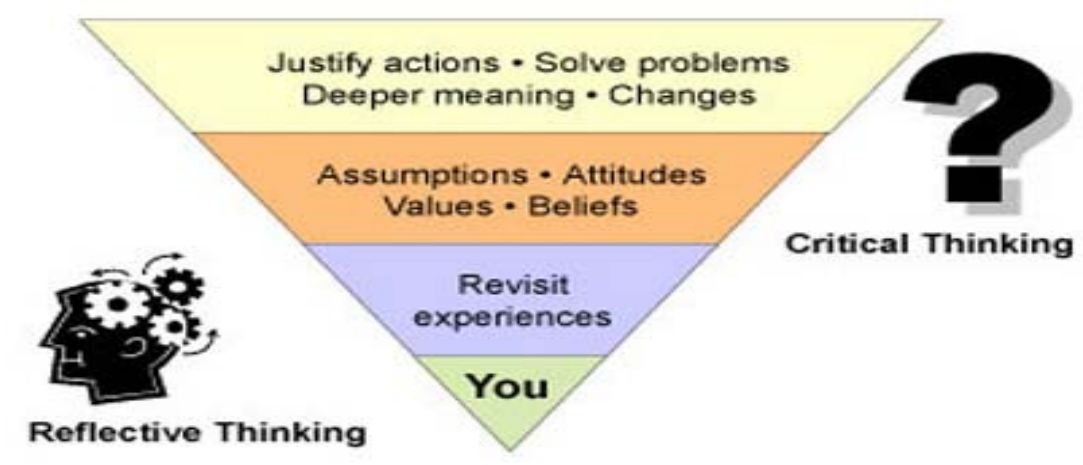

Figure 1. Reflective writing is:

- your response to experiences, opinions, events or new information

- your response to thoughts and feelings 
- a way of thinking to explore your learning

- $\quad$ an opportunity to gain self-knowledge

- a way to achieve clarity and better understanding of what you are learning

- a chance to develop and reinforce writing skills

- a way of making meaning out of what you study

Reflective writing is not:

- just conveying information, instruction or argument

- $\quad$ pure description, though there may be descriptive elements

- straightforward decision or judgment (e.g. about whether something is right or wrong, good or bad)

- $\quad$ simple problem-solving

- a summary of course notes

- a standard university essay

Types of reflective writing

- $\quad$ Learning journals/logs

- Practicum journals

- Reflection papers

- Response papers

- Integration papers

- $\quad$ Portfolio entries. (Brookfield, S 1987)

A big reason for reflective writing is that it's a means of thinking for me. Writing freely, whether it's jotting down ideas on the spur of the moment or sitting down deliberately to think and work through ideas, helps the ideas to come. And beyond that, once the ideas get down on to paper writing about them helps me to clarify them in my mind. (Burton, 2007, Response \#6)[Writing is a means of] thinking widely and deeply about what I do, and why (Burton, 2007, Response \#64)

\section{Research Questions}

To fulfill of the objectives, the following research questions were addressed:

RQ 1: Does reflective writing have a significant impact on EFL learners' writing achievement? 
RQ 2: Does reflective writing have a significant impact on EFL learners' vocabulary achievement?

RQ 3: Does reflective writing have a significant impact on EFL learners' critical thinking?

\section{Methodology}

\subsection{Participants}

In this study 60 out of 90 female intermediate EFL learners were selected from Tehran University of Medical Sciences. The students were at BS level, and were taking their general English course .They were non-randomly selected and homogenized through a preliminary English test (PET). They were assigned to two groups and four classes. One group was assigned as the control group and the other as the experimental group. They were selected based on their scores which fell one standard deviation above and below the mean of their PET scores. The participants' age range was between18-20. At the beginning of the study the PET test which was used to homogenize the participants was piloted on 30 female learners with the same characteristics of age and proficiency level as the target group. The writing section of the PET test was scored by two raters (the teacher and her colleague). The teacher of two classes was the researcher. The whole term consisted of 10 sessions spanning over one and a half month.

\subsection{Instruments}

In order to accomplish the purpose of the study, the following three instruments were utilized:

\subsubsection{A Preliminary English Test (PET)}

A preliminary English test (PET) was administered for determining the proficiency level of the participants. The test was piloted on a sample group consisting of 30 learners with the same characteristics as the target sample. This test covers the four main language skills: reading, writing, listening, and speaking. In this study two sections of this test were used to homogenize the participants. Reading section had 5 parts and 34 reading comprehension questions while writing section consisted of 3 parts and 8 questions. In the first part there are some sentences and for each question, EFL learners should complete the second sentences so that it means the same as the first. In the second part there is topic and the EFL learners should write 35-45 words on their answer sheet. In the last part there are two questions and the EFL learners should write an answer in about 100 words to one of the questions on their answer sheet. The participants were expected to answer the questions in 1 hour and 30 minutes (45 minutes for reading section and 45 minutes for writing section). Item facility, item discrimination and reliability of this test were calculated. At the end of the course, all the participants in the two groups underwent another PET writing test as a posttest in order for the researcher to see whether any significant differences existed among the mean scores of the two groups on the test. It is worth mentioning that the same rating scale that was used to rate the writing test prior to the treatment was used to score this test. In order to rate all the writings in this study the researcher used the General Mark Schemes for writing by 
Cambridge. Writings were rated on five aspects of writing: content, organization, vocabulary, and language use. The rating was done on the basis of criteria stated in the rating scale, and possible range of score was $0-5$ and later inter- rater reliability of the two raters' scores was calculated.

\subsubsection{The Vocabulary Pre-treatment test}

A test of vocabulary was made by the researcher involving 70 vocabularies which were supposed to be taught to the learners and be included in the posttest. The researcher selected the items from based of Access book. This book included some reading passages and the researcher could find the vocabularies for vocabulary pre test and vocabulary post test and that was the basis of the selection of the vocabularies. The vocabularies were in the form of multiple choice questions. The time allocated to this test was 75 minutes and it was administered 5 days after the administration of PET test. Each item was given one point. This test was administered to detect what vocabulary items the participants were not familiar with so that they could be included within the instruction plan and the post test. And as a result of participants taking the test, 20 words that were known to some respondents were excluded from the list of the vocabulary intended to be taught to the learners.

\subsubsection{The Vocabulary posttest}

A Vocabulary achievement posttest was made by the teacher involving 50 multiple choice items which the learners showed that they were not familiar with on the pre-treatment test and were taught to them during the instructions. It consisted of 50 vocabulary items (minus 20 known vocabularies that the learners showed to know in the 70 -item pre-treatment test.). The test was administered at the end of the course. The time allocated to this test was 60 minutes. Each item was given one point. The test was piloted on 30 participants who had the same characteristics of the main participants of the study. The reliability of the test was 0.92 .

\subsubsection{Honey's of Critical Thinking questionnaire}

The Critical Thinking Questionnaire intends to explore what a person might or might not do when thinking critically about a subject. Developed by Honey (2000), the questionnaire aims at evaluating the three main skills of comprehension, analysis, and evaluation of the participants. The Persian translated and validated version of the test by Naeini (2005) was used in order to make sure of the participants 'full comprehension.

It is Likert- type questionnaire with 30 items that allows researchers to investigate the learners' ability in note- taking, summarizing, questioning, paraphrasing, researching, inferencing, discussing, classifying, outlining, comparing and contrasting, distinguishing, synthesizing, inductive and deductive reasoning.

The participants were asked to rate the frequency of each category they use on a 5 point Liker_scale, ranging from never ( 1 point), seldom ( 2 points), sometimes ( 3 points), often (4 points), to always (5 points). Therefore the participants' scores range within 30 to 150 with the interpretation that the higher the score, the better critical thinker a person is. 


\subsection{Procedure}

The procedure of the study was sequenced as follow:

Prior to the start of the main student, the researcher piloted the PET on 30 learners bearing similar characteristics to the target sample. Two parts of the PET test were administered: the reading and writing sections. The scores of the PET test were calculated out of 42 because the test had 42 items and each item was given one point. The students answered the questions in 1 hour and 30 minutes. The reliability and item analyses of the PET test were estimated. After that the writing post test had to be piloted so, the researcher administered the writing post test which was a part of different version of the PET test. The writing post test consisted of 8 writing questions as described above.

At the next step, the piloted PET was administered to 90 EFL learners, and based on their mean score, 60 learners who scores one standard deviation below and above the mean were selected as the main participants of the study. Then, they were randomly assigned as the experimental and control groups. Then the two groups were given the critical thinking questionnaire. After homogenizing the participants in terms of their English general proficiency, the researcher intended to find participants' unknown vocabularies. Therefore she administered a vocabulary test to remove the known vocabularies from the test. The teacher-made vocabulary test consisted of 70 items but 20 items were participants' known vocabularies so, the researcher removed the known items from the test. The writing level of two groups was compared before the treatment. The researcher made sure that there was no significant difference between the two groups' PET writing scores at the outset. Afterwards, the researcher compared them regarding their critical thinking, by giving them the critical thinking questionnaire. As there were two variables that the researcher had to compare the two groups on, two t tests on the obtained scores were run to make sure that they were homogeneous regarding these dependent variables at the outset. The respondents were provided with the instructions of filling the critical thinking questionnaire, bearing in mind that there was no right or wrong answers. It is worth mentioning that in order to encourage the participants to answer with more care and honesty, they were assured that their responses to the instruments were planned to be used only for gathering information for purposes of this research and the results were not linked to any form of classroom evaluation, so the students were not required to write their names on the questionnaires. It should be also noted that the researcher was present while participants were responding to questionnaires to provide further explanations if required. The semester included 17 sessions and 10 sessions were dedicated to the treatment. In the treatment stage two different instructions were practiced as the tasks in two groups. Each group consisted of 30 female students. Each session was started as follow:

Since the researcher could not put the participants in two classes of thirty she divided them into four classes; four classes of fifteen. Therefore there were two classes in each group. First of all in each group the teacher taught five new words in each session. The teacher wrote the new vocabularies on the board, and for each session she presented some aspects of the words such as pronunciation, synonyms or antonyms. The teacher asked the students to make some 
sentences which include the new words to make sure that all of the participants acquired the vocabularies. First, in the control group the teacher presented some introductory remarks to students about writing. She used a writing checklist which made it easier for the students to use the writing process. It included directions for writing. The teacher taught steps of the directions. She used writing prompt and underneath the prompt was a sample prewriting that one student did. The teacher taught the writing process with writing prompt according to the lesson plan in 10 sessions. The teacher put the students in groups and allowed them to correct their papers by the members of the group. It got the students to benefit from group assistance as a peer-learning experience with more resource value than one to one peer sharing. The teacher asked the class to offer corrections. The class really focused on every group finished writing to see if it was correct or not. The teacher wrote comments as a feedback on a separate page and staples it to the front of the paper. All the instructions in this group were based on the routine procedures employed at the context where the investigation was carried out.

In the experimental group the teacher started with presenting some reflective writing definitions. She introduced exercises as a means to demonstrate that there are different depths in reflection and that deeper reflection probably equates better learning. First of all in each group the teacher they were taught new words. The teacher wrote the new vocabularies on the board for each session she presented some aspects of the words such as pronunciation, synonyms or antonyms. The teacher asked the students to make some sentences to make sure that all of the participants acquired the vocabularies. Next they were requested to use these vocabularies for writing reflectively. Reflective writing exercises included four accounts of an incident, and they read them one after the other to consider what features they thought were reflective. The procedure for the exercise was described as an individually process The teacher told the students to turn to the first account and read it quietly to themselves considering what features that they think are reflective. When it was evident that most people had read the first account, the students were invited to discuss the account in groups and identify where and how it was reflective. Each session the participants read only one account. After the last account, they were asked to go back through all of the accounts and to identify features of the reflection that progressively change through the accounts. For example, the accounts change from being 'story' to focusing on issues in the incident. After four sessions the participants started to write reflectively according to what they learnt. All of the reflective writing prompt was like this. The teacher taught the reflective writing process and writing prompt according to the lesson plan in 10 sessions. After 10 sessions the participants were taught 50 new vocabularies based on lesson plans. Finally, at the end of the course the participants were given the vocabulary post test which included 50 multiple choice items based on the covered vocabularies during the treatment stage. Each item was given 1 point and the time allocated for this test was 60 minutes. The piloted vocabulary post test was administered to the participants in the next session. The participants were given the writing part of PET test which included 8 questions and critical thinking questionnaire which include 30 questions. 


\section{Macrothink}

At the final step, the statistical procedures were done by the researcher to check whether reflective writing had significant effect on writing achievement, vocabulary achievement and critical thinking. A Multivariate Analysis of Variance was run to compare the control and experimental groups' on the dependent variables critical thinking, vocabulary and writing achievement.

\subsection{Data Analysis}

The analyses of this study were both descriptive and inferential statistics. The descriptive statistics was related to calculating mean and standard deviation of the scores on the piloted test for homogenizing participants. Cronbach Alpha was used for estimating the inter-rater reliability of PET writing. T tests were conducted to compare the two groups at the pre-treatment stage regarding their writing critical thinking skills. Finally, a MANOVA was run to compare the two groups at the post-treatment stage in terms of their vocabulary, and writing achievement as well as their critical thinking.

\section{Results}

This study attempted to investigate the impact of reflective writing on writing achievement, vocabulary achievement and critical thinking of intermediate EFL learners. In order to test the study's hypotheses, a series of statistical analysis were conducted by the researcher. This chapter outlines the data analysis procedure and results of the study. The procedure of data analysis consists of piloting process, participation selection, post test administration and testing the hypotheses. The result of the study is discussed in this chapter. This study tested the following hypotheses;

$\mathrm{H} 0_{1}$. Reflective writing has no significant effect on EFL learners' writing ability.

$\mathrm{H}_{2}$. Reflective writing has no significant effect on EFL learners' vocabulary achievement.

$\mathrm{HO}_{3}$. Reflective writing has no significant effect on EFL learners' critical thinking.

\subsection{Piloting PET}

The first stage was to pilot the PET test in order to homogenize the students based on their general proficiency. The reliability of the PET test was estimated as reported below.

Table 1. Descriptive Statistics of PET Piloting

\begin{tabular}{|l|l|l|l|l|l|l|l|}
\hline & N & Range & Minimum & Maximum & Mean & Std. Deviation & Variance \\
\hline PET piloting & 30 & 29 & 7 & 36 & 21.4 & 11.57 & 134.00 \\
Valid N (listwise) & 30 & & & & & & \\
\hline
\end{tabular}


Table 2. Reliability Statistics

\begin{tabular}{|l|l|l|}
\hline Cronbach's Alpha & Cronbach's Alpha Based on Standardized Items & N of Items \\
\hline .944 & .944 & 42 \\
\hline
\end{tabular}

As it is shown in table 2 the reliability of the PET test was estimated 0.94. All items went through item analyses and no item was discarded.

\subsection{Piloting the vocabulary post test}

Table 3. Descriptive Statistics of vocabulary post test-Piloting

\begin{tabular}{|l|l|l|l|l|l|l|l|}
\hline & $\mathrm{N}$ & Range & Minimum & Maximum & Mean & Std. Deviation & Variance \\
\hline vocabulary test piloting & 30 & 29 & 15 & 44 & 29.43 & 11.57 & 133.97 \\
Valid N (listwise) & 30 & & & & & & \\
\hline
\end{tabular}

Table 4. Reliability Statistics

\begin{tabular}{|l|l|l|}
\hline Cronbach's Alpha & Cronbach's Alpha Based on Standardized Items & N of Items \\
\hline .928 & .928 & 50 \\
\hline
\end{tabular}

The vocabulary post test was administered to 30 students in order to pilot the test. The reliability of the test was estimated 0.92 . Regarding the item analyses procedure no item was removed.

\subsection{Estimating inter rater reliability for writing scores}

The inter rater reliability of the PET writing scores was estimated based on two raters' scores given to the participants' writing scores. First inter-rater reliability of the scores given by both raters to the two groups was estimated. 
Table 5. Descriptive Statistics

\begin{tabular}{|l|l|l|l|l|l|l|}
\hline & $\mathrm{N}$ & Mean & Std. Deviation & \multicolumn{2}{|l|}{ Skewness } & \multicolumn{2}{l|}{ Skewnwss ratios } \\
\cline { 2 - 7 } & Statistic & Statistic & Statistic & Statistic & Std. Error & \\
\hline Experimental Rater 1 & 30 & 4.1333 & 1.99540 & -.169 & .427 & .39 \\
Eperimental Rater 2 & 30 & 4.3000 & 1.84110 & -.049 & .427 & .11 \\
\hline
\end{tabular}

The above table shows that the sets of scores given to the experimental group's writings were normally distributed as the skewness ratios fall between \pm 1.96 . So, the normality assumption for Pearson correlation calculation is met.

Table 6. Correlations

\begin{tabular}{|ll|l|l|}
\hline & & $\begin{array}{l}\text { Experimental } \\
\text { Rater 1 }\end{array}$ & $\begin{array}{l}\text { Eperimental Rater } \\
2\end{array}$ \\
\hline Experimental Rater 1 & Pearson Correlation & 1 & $.984^{* *}$ \\
& Sig. (2-tailed) & .000 \\
& $\mathrm{~N}$ & 30 & 30 \\
\hline Eperimental Rater 2 & Pearson Correlation & $.984^{* *}$ & 1 \\
& Sig. (2-tailed) & .000 & 30 \\
& $\mathrm{~N}$ & 30 & 30 \\
\hline
\end{tabular}

**. Correlation is significant at the 0.01 level (2-tailed).

The above table shows that the correlation between the two sets of scores was significant $(r=.98, p=.000<.05)$, hence the inter-rater reliability. Therefore, the mean of the scores could safely be used for further calculations. 
Table 7. Descriptive Statistics

\begin{tabular}{|l|l|l|l|l|l|l|}
\hline & $\mathrm{N}$ & Mean & Std. Deviation & \multicolumn{2}{|l|}{ Skewness } & \multicolumn{2}{|l|}{$\begin{array}{l}\text { Skewness } \\
\text { ratios }\end{array}$} \\
\cline { 2 - 8 } & Statistic & Statistic & Statistic & Statistic & Std. Error & \\
\hline Control Rater 1 & 30 & 4.1667 & 1.85850 & -.122 & .427 & -.28 \\
Comtrol Rater2 & 30 & 4.3333 & 1.68836 & -.106 & .427 & -.24 \\
\hline
\end{tabular}

As the above table shows, the skewness ratios both fall within the normality range of \pm 1.96 , hence the normality of both sets of scores.

Table 8. Correlations

\begin{tabular}{|ll|l|l|}
\hline & & CGrater1 & CGrater2 \\
\hline CGrater1 & Pearson Correlation & 1 & $.982^{* *}$ \\
& Sig. (2-tailed) & .000 \\
& $\mathrm{~N}$ & 30 & 30 \\
\hline CGrater2 & Pearson Correlation & $.982^{* *}$ & 1 \\
& Sig. (2-tailed) & .000 & \\
& $\mathrm{~N}$ & 30 & 30 \\
\hline
\end{tabular}

**. Correlation is significant at the 0.01 level (2-tailed).

As depicted in the above table, the correlation between the scores given by both raters to the control group's writings turned out to be significant $(r=.98, p=.000<.05)$.

Furthermore, the researcher intended to see whether there was a significant difference between the writings of the two groups before the treatment. In order to calculate the t-test, the assumption of normality was checked. The following table shows the skewness information. 
Table 9. Descriptive Statistics

\begin{tabular}{|c|c|c|c|c|c|c|c|}
\hline & & $\mathrm{N}$ & Mean & Std. Deviation & \multicolumn{2}{|c|}{ Skewness } & \multirow[t]{2}{*}{$\begin{array}{l}\text { Skewness } \\
\text { ratios }\end{array}$} \\
\hline & & Statistic & Statistic & Statistic & Statistic & Std. Error & \\
\hline CGwriting & & 30 & 4.2500 & 1.76533 & -.088 & .427 & .20 \\
\hline $\begin{array}{l}\text { experimental } \\
\text { writing }\end{array}$ & G. & 30 & 4.2167 & 1.91042 & -.095 & .427 & .22 \\
\hline Valid N (listwise) & & 30 & & & & & \\
\hline
\end{tabular}

As the above table shows, the skewness ratios are both within the normality range. Therefore, the assumption of normality is met.

Table 10. Group Statistics

\begin{tabular}{|ll|l|l|l|l|}
\hline & grouping & $\mathrm{N}$ & Mean & Std. Deviation & Std. Error Mean \\
\hline writing & EG & 30 & 4.2167 & 1.91042 & .34879 \\
& CG & 30 & 4.2500 & 1.76533 & .32230 \\
\hline
\end{tabular}

The above table shows that the two groups obtained very similar mean scores on their writings before the treatment. The following table shows the result of the t-test. 
Table 11. Independent Samples Test

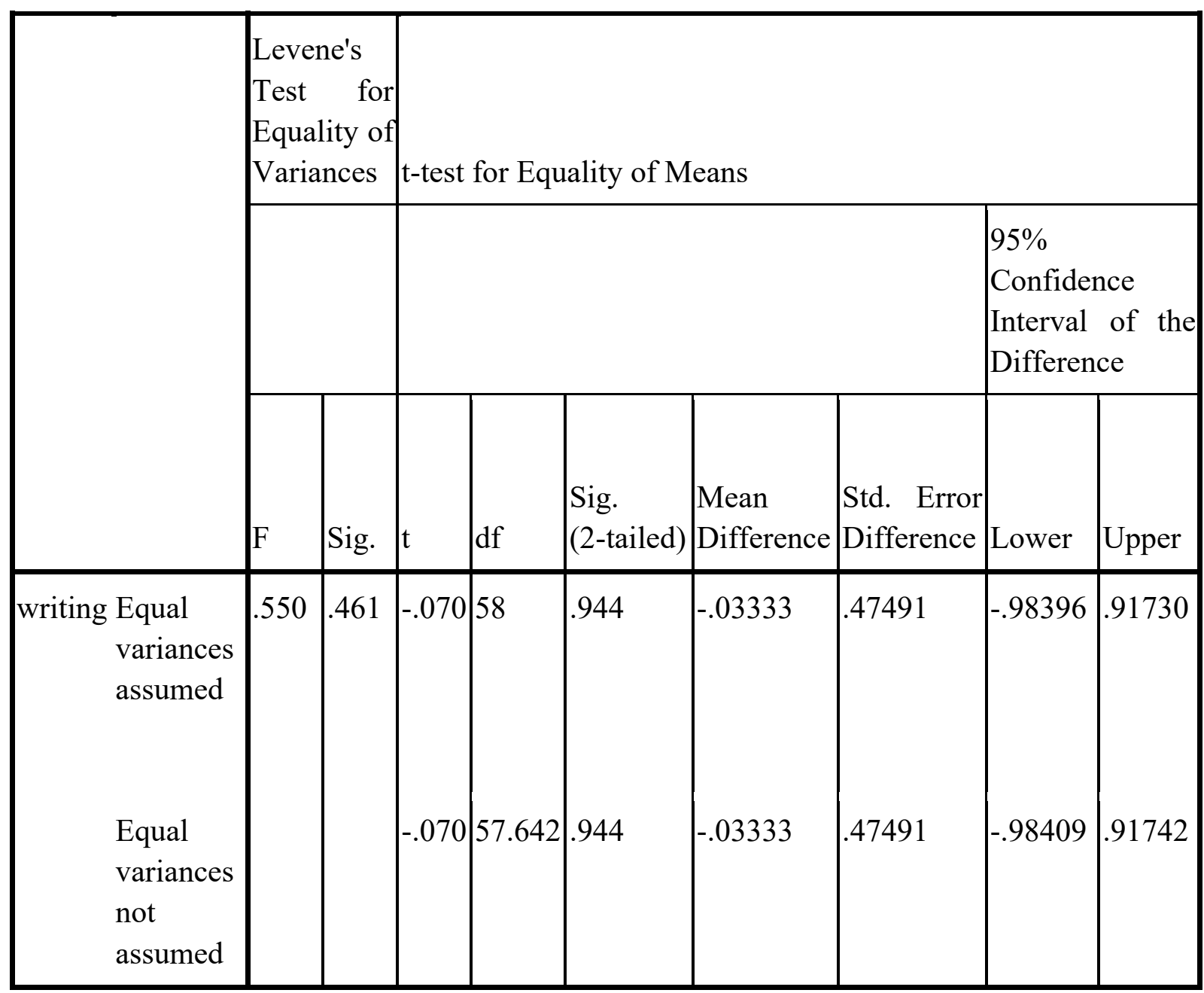

As illustrated in the above table, the assumption of homogeneity of variances is met $(\mathrm{F}=.55$, $\mathrm{p}=.46>.05)$. And, the difference between the two sets of scores turned out to be non-significant $(\mathrm{t}=.07, \mathrm{p}=.94>.05)$. Therefore, it is concluded that the two groups were homogeneous regarding their writing ability at the outset.

\subsection{Estimating critical thinking scores}

The homogeneity of the participants of the two groups regarding their critical thinking ability had to be ensured. The following table contained the skewness information of both sets of scores obtained by the two groups. 
Table 12. Descriptive Statistics

\begin{tabular}{|l|l|l|l|l|l|l|}
\hline & N & Mean & Std. Deviation & \multicolumn{2}{|l|}{ Skewness } & \multicolumn{2}{l|}{ Skewness ratios } \\
\cline { 2 - 7 } & Statistic & Statistic & Statistic & Statistic & Std. Error & \\
\hline ExG's CT scores & 30 & 79.1667 & 3.54365 & .132 & .427 & .30 \\
CG's CT scores & 30 & 79.0000 & 3.52332 & .061 & .427 & .14 \\
\hline
\end{tabular}

As exhibited in the above table, the skewness ratios fell within the normality range, hence both sets of scores were normally distributed.

Table 13. Group Statistics

\begin{tabular}{|ll|l|l|l|l|}
\hline & Grouping & $\mathrm{N}$ & Mean & Std. Deviation & Std. Error Mean \\
\hline CT scores & EG & 30 & 79.1667 & 3.54365 & .64698 \\
& CG & 30 & 79.0000 & 3.52332 & .64327 \\
\hline
\end{tabular}


Table 14. Independent Samples Test

\begin{tabular}{|c|c|c|c|c|c|c|c|c|c|}
\hline & \multicolumn{2}{|c|}{$\begin{array}{l}\text { Levene's } \\
\text { Test for } \\
\text { Equality of } \\
\text { Variances }\end{array}$} & \multicolumn{7}{|c|}{ t-test for Equality of Means } \\
\hline & \multirow[b]{2}{*}{$\mathrm{F}$} & \multirow[b]{2}{*}{ Sig. } & \multirow[b]{2}{*}{$\mathrm{T}$} & \multirow[b]{2}{*}{ df } & \multirow[b]{2}{*}{$\begin{array}{l}\text { Sig. } \\
(2 \text {-tailed) }\end{array}$} & \multirow[b]{2}{*}{$\mid \begin{array}{l}\text { Mean } \\
\text { Difference }\end{array}$} & \multirow[b]{2}{*}{$\begin{array}{l}\text { Std. Error } \\
\text { Difference }\end{array}$} & \multicolumn{2}{|c|}{$\begin{array}{l}95 \% \text { Confidence } \\
\text { Interval of the } \\
\text { Difference }\end{array}$} \\
\hline & & & & & & & & Lower & Upper \\
\hline $\begin{array}{lc}\text { CT } & \text { Equal } \\
\text { scores } & \text { variances } \\
& \text { assumed }\end{array}$ & .008 & .930 & .183 & 58 & .856 & .16667 & .91235 & -1.65959 & 1.99293 \\
\hline $\begin{array}{l}\text { Equal } \\
\text { variances } \\
\text { not } \\
\text { assumed }\end{array}$ & & & .183 & 57.998 & .856 & .16667 & .91235 & -1.65959 & 1.99293 \\
\hline
\end{tabular}

The above table shows that the homogeneity of variances assumption is met is $(F=.008$, $\mathrm{p}=.93>.05$ ). Also, the difference between the two means turned out to be non-significant $(\mathrm{t}=.18, \mathrm{p}=.85<.05)$. As such, it is concluded that the two groups were homogeneous regarding their critical thinking ability before the treatment.

\subsection{Testing the null hypotheses}

The research hypotheses were as follows:

- Reflective writing instruction does not significantly affect the EFL learners' writing achievement.

- $\quad$ Reflective writing instruction does not significantly affect the EFL learners' critical thinking ability.

- $\quad$ Reflective writing instruction does not significantly affect the EFL learners' vocabulary achievement.

As in this study there was one independent variable (reflective writing) and three dependent variables (writing, vocabulary and critical thinking), a MANOVA was needed to compare the performances of the learners on the posttests. Firstly the assumptions were checked by the researcher: 
- Normality

- Multicollinearity

- Outliers

- Equality of variances

As there were two raters who scored the writing posttests, the inter-rater reliability had to be checked. The following tables show the result:

Table 15. Correlation between the two raters' scores given to the experimental group

\begin{tabular}{|ll|l|l|}
\hline & & ExGrater1 & ExGrater2 \\
\hline ExGrater1 & Pearson Correlation & 1 & $.954^{* *}$ \\
& Sig. (2-tailed) & .000 \\
& $\mathrm{~N}$ & 30 & 30 \\
\hline ExGrater2 & Pearson Correlation & $.954^{* *}$ & 1 \\
& Sig. (2-tailed) & .000 & \\
& $\mathrm{~N}$ & 30 & 30 \\
\hline
\end{tabular}

**. Correlation is significant at the 0.01 level (2-tailed).

Table 16. Correlation between the two raters' scores given to the control group

\begin{tabular}{|ll|l|l|}
\hline & & CGrater1 & CGrater2 \\
\hline CGrater1 & Pearson Correlation & 1 & $.922^{* *}$ \\
& Sig. (2-tailed) & .000 \\
& $\mathrm{~N}$ & 30 & 30 \\
\hline CGrater2 & Pearson Correlation & $.922^{* *}$ & 1 \\
& Sig. (2-tailed) & .000 & \\
& $\mathrm{~N}$ & 30 & 30 \\
\hline
\end{tabular}

**. Correlation is significant at the 0.01 level (2-tailed).

Since in this study there were three dependent variables (writing, CT, and vocabulary), and one independent variable (reflective writing instruction), a MANOVA had to be run to test 


\section{Macrothink}

the hypotheses. Firstly, the assumptions of normality (univariate and multivariate), outliers, multicollinearity, and Homogeneity of variance-covariance were checked.

The following table shows the descriptive statistics containing skewness information to meet the first assumption of univariate normality:

Table 17. Descriptive Statistics of the posttest scores of the two groups

\begin{tabular}{|l|l|l|l|l|l|l|}
\hline & $\mathrm{N}$ & Mean & Std. Deviation & \multicolumn{2}{|l|}{ Skewness } & Skewness ratios \\
\cline { 2 - 7 } & Statistic & Statistic & Statistic & Statistic & Std. Error & \\
\hline ExG's witing posttest & 30 & 6.4833 & .81456 & -1.532 & .427 & -3.58 \\
CG 's writing posttest & 30 & 4.1500 & .93909 & -.167 & .427 & -.391 \\
ExG's CT posttest & 30 & 129.1667 & 3.54365 & .132 & .427 & .309 \\
CG's CT posttest & 30 & 89.0000 & 3.52332 & .061 & .427 & .142 \\
ExG's vcb posttest & 30 & 38.2333 & 3.39049 & .672 & .427 & 1.57 \\
CG's vcb posttest & 30 & 29.2000 & 2.65746 & -.018 & .427 & -.042 \\
Valid N (listwise) & 30 & & & & & \\
\hline
\end{tabular}

As all the skewness ratios, except for the experimental writing scores (the first row), fall within the normality range of \pm 1.96 , it is concluded that almost all the distributions turned out to be normal. MANOVA is robust to modest violations of normality except where the violations are due to outliers (Pallant, 2007). Therefore, outliers were visually checked through the following box plots:

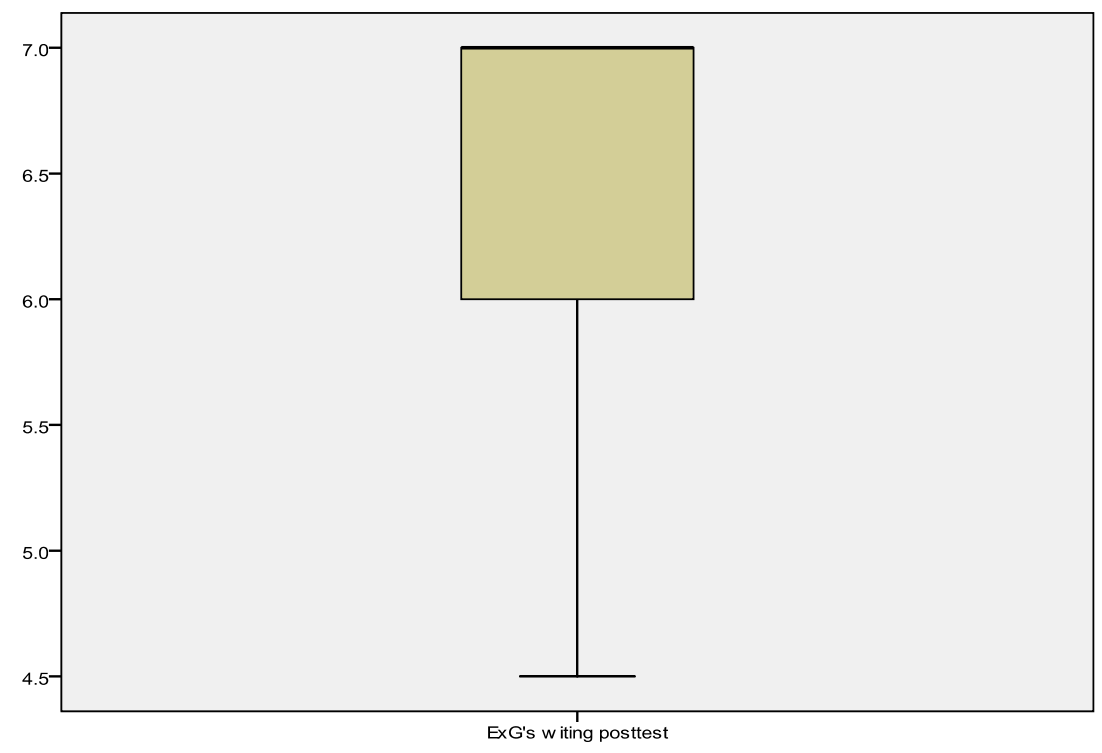

Figure 1. Box plot representing the distribution of the ExG's writing posttest scores 


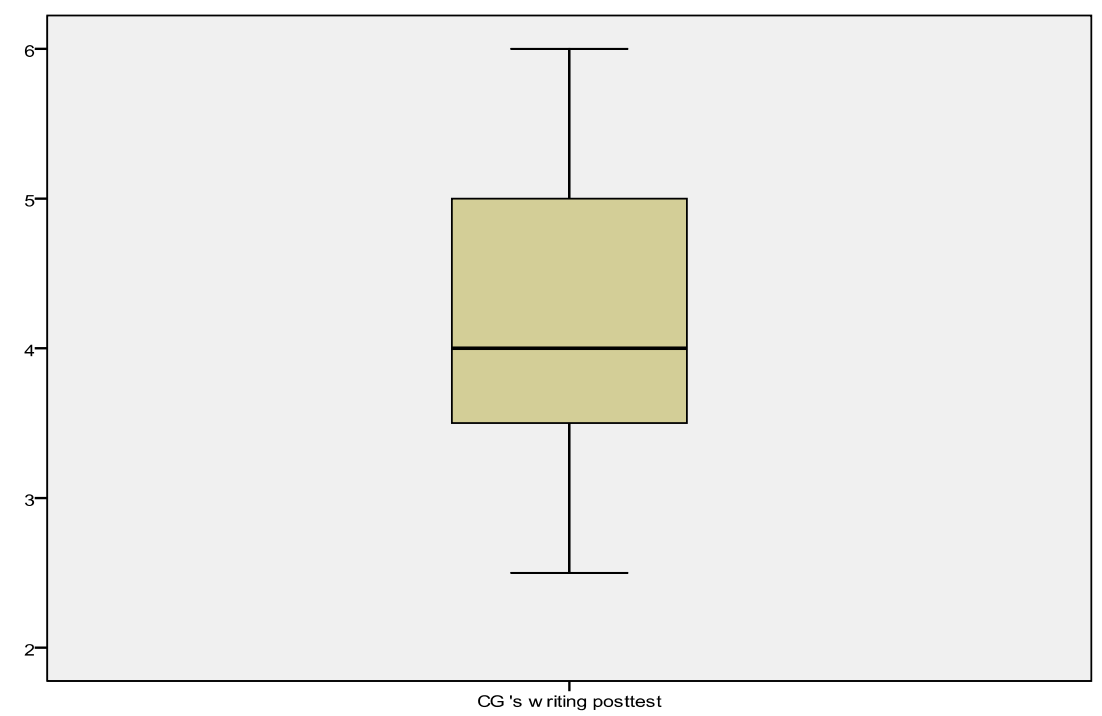

Figure 2. Box plot representing the distribution of CG's writing posttest scores

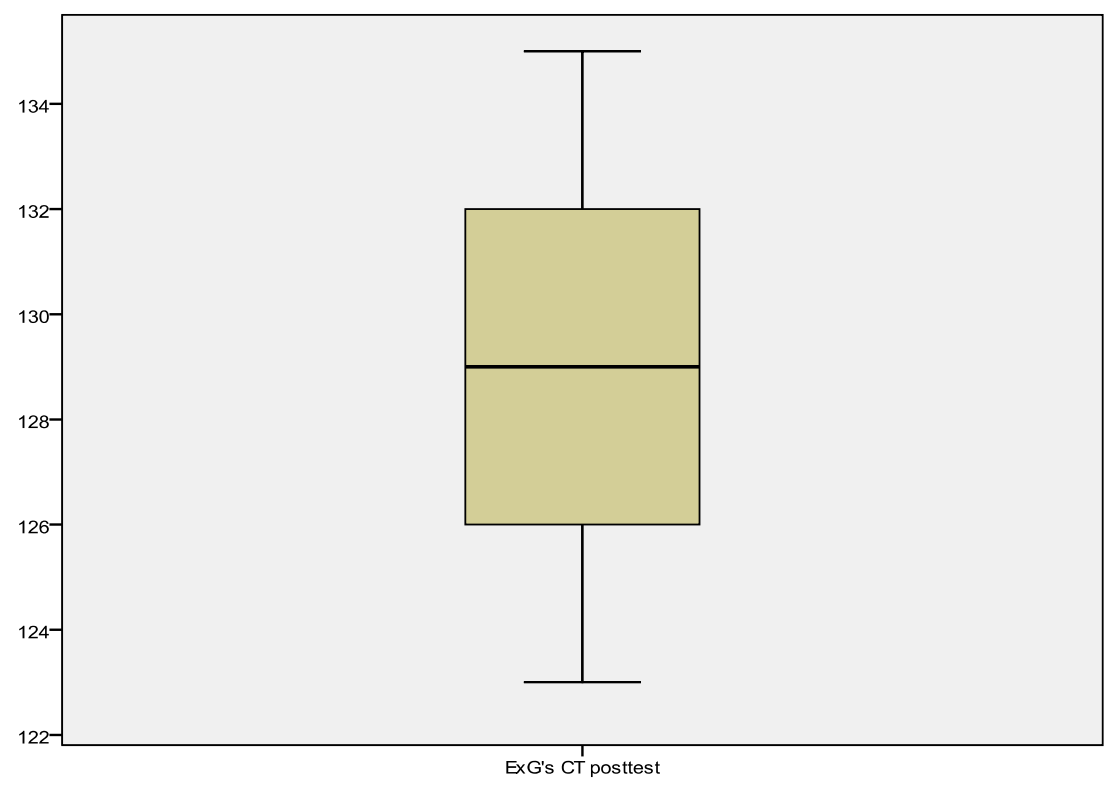

Figure 3. Box plot representing the distribution of the ExG's CT posttest scores 


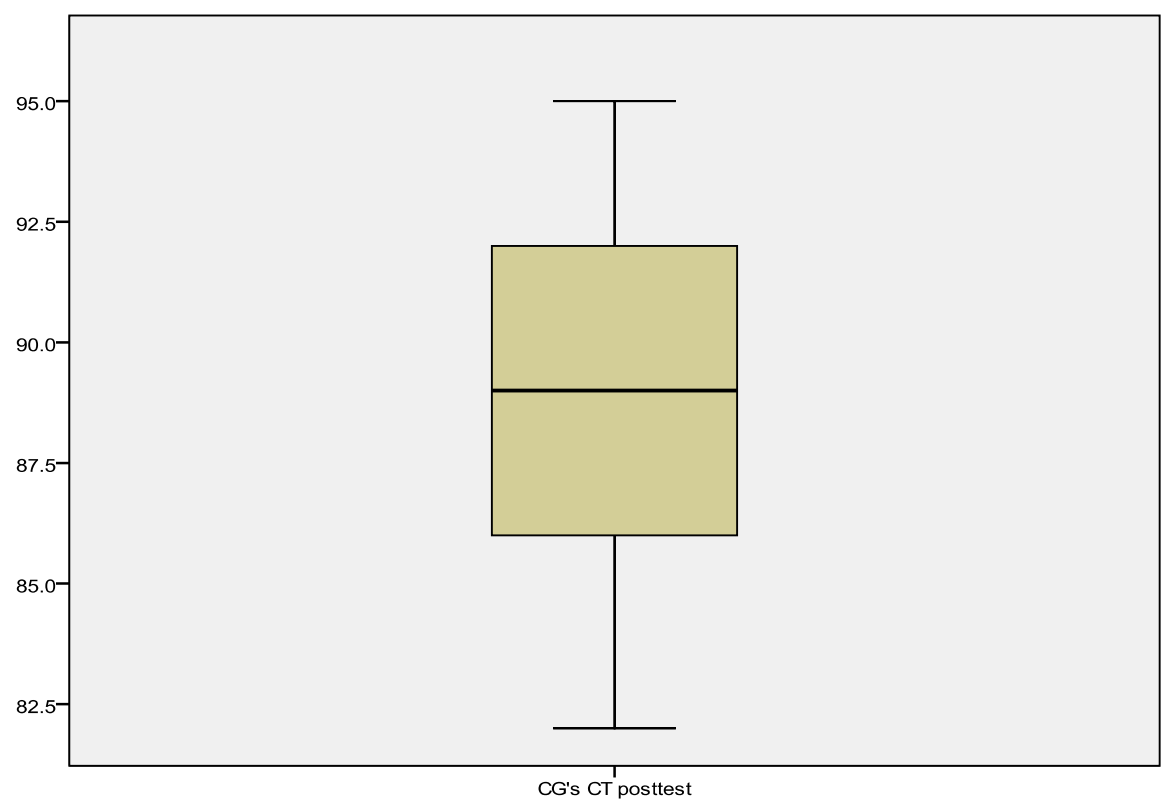

Figure 4. Box plot representing the distribution of the CG's CT posttest scores

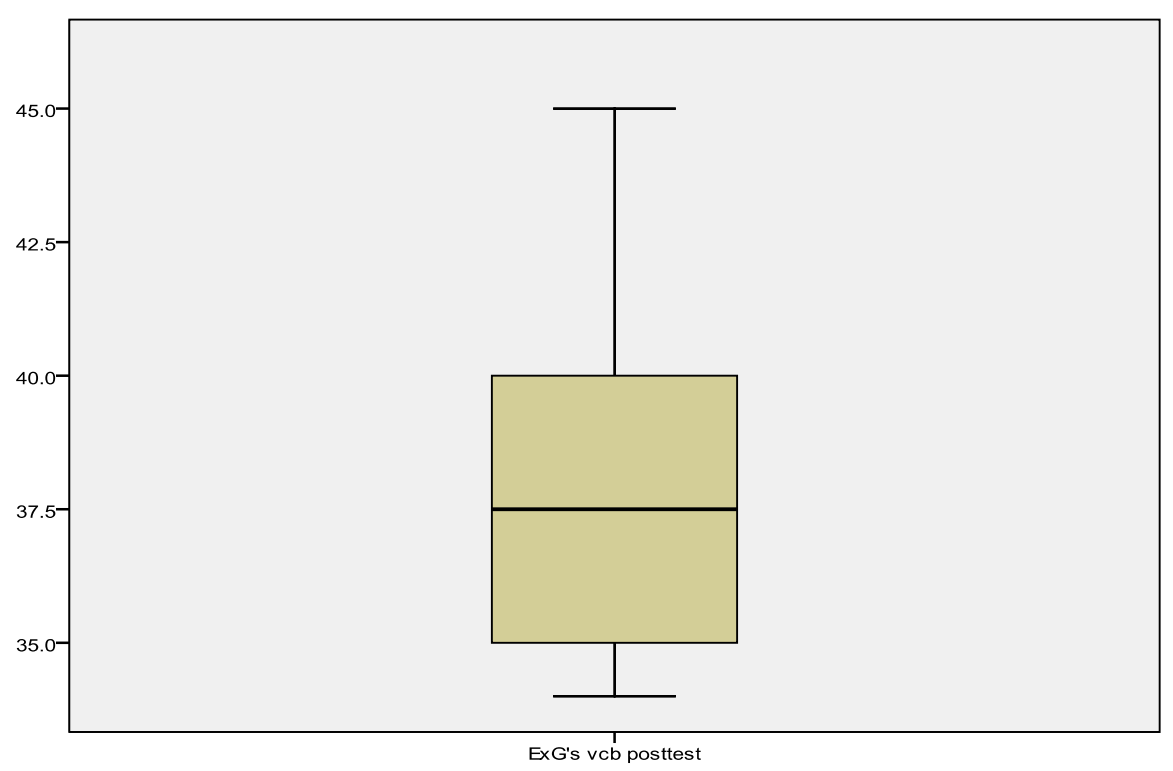

Figure 5. Box plot representing the distribution of the ExG's vcb posttest scores 


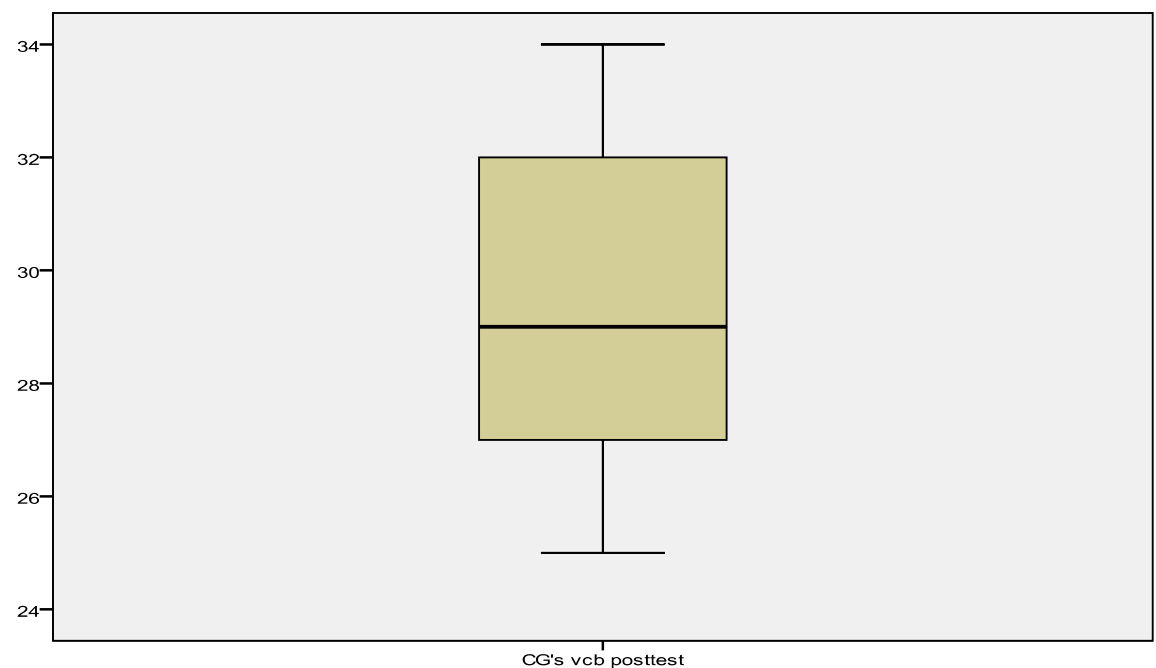

Figure 6. Box plot representing the distribution of the CG's vcb posttest scores

As in none of the above box plots outliers are indicated by circles or stars, it is therefore concluded that there were no outliers in the six sets of scores.

The following table was generated to ensure the multivariate normality of the distributions:

Table 18. Residuals Statistics ${ }^{\mathrm{a}}$

\begin{tabular}{|l|l|l|l|l|l|}
\hline & Minimum & Maximum & Mean & Std. Deviation & N \\
\hline Predicted Value & .8953 & 2.1618 & 1.5000 & .49917 & 60 \\
Std. Predicted Value & -1.211 & 1.326 & .000 & 1.000 & 60 \\
Standard Error of Predicted Value & .014 & .029 & .018 & .004 & 60 \\
Adjusted Predicted Value & .8895 & 2.1724 & 1.5000 & .49938 & 60 \\
Residual & -.19849 & .12460 & .00000 & .07116 & 60 \\
Std. Residual & -2.718 & 1.706 & .000 & .974 & 60 \\
Stud. Residual & -2.830 & 1.736 & .000 & 1.003 & 60 \\
Deleted Residual & -.21517 & .12907 & -.00002 & .07548 & 60 \\
Stud. Deleted Residual & -3.029 & 1.769 & -.006 & 1.025 & 60 \\
Mahal. Distance & 1.042 & 8.590 & 2.950 & 1.736 & 60 \\
Cook's Distance & .000 & .168 & .015 & .025 & 60 \\
Centered Leverage Value & .018 & .146 & .050 & .029 & 60 \\
\hline
\end{tabular}

a. Dependent Variable: grouping 
As depicted in the above table, the Mahal. Distance maximum value does not exceed the critical value of 16.27 for three dependent variables (Pallant, 2007, p.280). Therefore, it is concluded that there were no significant outlier, hence the assumption was met.

The multicollinearity condition was also checked through the following table:

Table 19. Correlations among the three dependent variables

\begin{tabular}{|ll|l|l|l|}
\hline & & Writing & CT & Vcb \\
\hline writing & Pearson Correlation & 1 & $.786^{* *}$ & $.638^{* *}$ \\
& Sig. (2-tailed) & & .000 & .000 \\
& N & 60 & 60 & 60 \\
\hline CT & Pearson Correlation & $.786^{* *}$ & 1 & $.793^{* *}$ \\
& Sig. (2-tailed) & .000 & .000 \\
& N & 60 & 60 & 60 \\
\hline vcb & Pearson Correlation & $.638^{* *}$ & $.793^{* *}$ & 1 \\
& Sig. (2-tailed) & .000 & .000 & \\
& N & 60 & 60 & 60 \\
\hline
\end{tabular}

**. Correlation is significant at the 0.01 level (2-tailed).

As exhibited in the above table, the correlations among the three dependent variables turned out to be not very low, and less than $.8(.63, .79$, and .78), so there was no reason for concern.

The homogeneity of variance-covariance assumption was also checked through the following test:

Table 20. Box's Test of Equality of Covariance Matrices ${ }^{\mathrm{a}}$

\begin{tabular}{|l|l|}
\hline Box's M & 2.613 \\
F & 411 \\
df1 & 6 \\
df2 & 24373.132 \\
Sig. & .872 \\
\hline
\end{tabular}

As displayed in the above table, the sig value is larger than the .05 critical value. Hence, the assumption was not violated. 
The following table shows the result of the check for the homogeneity of variances:

Table 21. Levene's Test of Equality of Error Variances ${ }^{a}$

\begin{tabular}{|l|l|l|l|l|}
\hline & F & df1 & df2 & Sig. \\
\hline writing & 1.512 & 1 & 58 & .224 \\
CT & .008 & 1 & 58 & .930 \\
vcb & 1.900 & 1 & 58 & .173 \\
\hline
\end{tabular}

As shown in the above table, all the sig values belonging to the three dependent variables are larger than .05, hence the assumption was met.

With all the assumptions met, the MANOVA analysis was legitimate to run. The following tables show the result thereof:

Table 22. Descriptive Statistics

\begin{tabular}{|ll|l|l|l|}
\hline & Grouping & Mean & Std. Deviation & N \\
\hline writing & ExG & 6.4833 & .81456 & 30 \\
& CG & 4.1500 & .93909 & 30 \\
& Total & 5.3167 & 1.46417 & 60 \\
\hline CT & ExG & 129.1667 & 3.54365 & 30 \\
& CG & 89.0000 & 3.52332 & 30 \\
& Total & 109.0833 & 20.55360 & 60 \\
\hline vcb & ExG & 38.2333 & 3.39049 & 30 \\
& CG & 29.2000 & 2.65746 & 30 \\
& Total & 33.7167 & 5.46512 & 60 \\
\hline
\end{tabular}

In the above table, it is shown that in all the posttest, the experimental group outperformed the control group gaining a higher mean score. The following table shows the significance of this supremacy: 


\section{Macrothink}

Table 23. Multivariate Tests ${ }^{\mathrm{b}}$

\begin{tabular}{|c|c|c|c|c|c|c|c|}
\hline Effect & & Value & $\mathrm{F}$ & Hypothesis df & Error df & Sig. & Partial Eta Squared \\
\hline \multirow[t]{4}{*}{ Intercept } & Pillai's Trace & .999 & $29146.789^{\mathrm{a}}$ & 3.000 & 56.000 & .000 & .999 \\
\hline & Wilks' Lambda & .001 & $29146.789^{\mathrm{a}}$ & 3.000 & 56.000 & .000 & .999 \\
\hline & Hotelling's Trace & 1561.435 & $29146.789^{\mathrm{a}}$ & 3.000 & 56.000 & .000 & .999 \\
\hline & Roy's Largest Root & 1561.435 & $29146.789^{a}$ & 3.000 & 56.000 & .000 & .999 \\
\hline \multirow[t]{4}{*}{ Grouping } & Pillai's Trace & .980 & $918.605^{\mathrm{a}}$ & 3.000 & 56.000 & .000 & .980 \\
\hline & Wilks' Lambda & .020 & $918.605^{\mathrm{a}}$ & 3.000 & 56.000 & .000 & .980 \\
\hline & Hotelling's Trace & 49.211 & $918.605^{a}$ & 3.000 & 56.000 & .000 & .980 \\
\hline & Roy's Largest Root & 49.211 & $918.605^{\mathrm{a}}$ & 3.000 & 56.000 & .000 & .980 \\
\hline
\end{tabular}

a. Exact statistic

b. Design: Intercept + grouping

The above table depicts that the Wilk's Lambda sig value for grouping is less than .05, implying that there were significant differences among the posttest scores of the two groups. The following table shows where these differences were: 
Table 24. Tests of Between-Subjects Effects

\begin{tabular}{|c|c|c|c|c|c|c|c|}
\hline Source & Dependent Variable & $\begin{array}{l}\text { Type III Sum of } \\
\text { Squares }\end{array}$ & Df & Mean Square & $\mathrm{F}$ & Sig. & Partial Eta Squared \\
\hline Corrected Model & $\begin{array}{l}\text { writing } \\
\text { CT } \\
\text { vcb }\end{array}$ & $\begin{array}{l}81.667^{\mathrm{a}} \\
24200.417^{\mathrm{b}} \\
1224.017^{\mathrm{c}}\end{array}$ & 1 & $\begin{array}{l}81.667 \\
24200.417 \\
1224.017\end{array}$ & $\begin{array}{l}105.690 \\
1938.261 \\
131.916\end{array}$ & $\begin{array}{l}.000 \\
.000 \\
.000\end{array}$ & $\begin{array}{l}.646 \\
.971 \\
.695\end{array}$ \\
\hline Intercept & $\begin{array}{l}\text { writing } \\
\mathrm{CT} \\
\mathrm{vcb}\end{array}$ & $\begin{array}{l}1696.017 \\
713950.417 \\
68208.817\end{array}$ & $\mid \begin{array}{l}1 \\
1 \\
1\end{array}$ & $\begin{array}{l}1696.017 \\
713950.417 \\
68208.817\end{array}$ & $\begin{array}{l}2194.919 \\
57181.759 \\
7351.090\end{array}$ & $\begin{array}{l}.000 \\
.000 \\
.000\end{array}$ & $\begin{array}{l}.974 \\
.999 \\
.992\end{array}$ \\
\hline Grouping & $\begin{array}{l}\text { writing } \\
\mathrm{CT} \\
\mathrm{vcb}\end{array}$ & $\begin{array}{l}81.667 \\
24200.417 \\
1224.017\end{array}$ & $\begin{array}{l}1 \\
1\end{array}$ & $\begin{array}{l}81.667 \\
24200.417 \\
1224.017\end{array}$ & $\begin{array}{l}105.690 \\
1938.261 \\
131.916\end{array}$ & $\begin{array}{l}.000 \\
.000 \\
.000\end{array}$ & $\begin{array}{l}.646 \\
.971 \\
.695\end{array}$ \\
\hline Error & $\begin{array}{l}\text { writing } \\
\mathrm{CT} \\
\mathrm{vcb}\end{array}$ & $\begin{array}{l}44.817 \\
724.167 \\
538.167\end{array}$ & $\begin{array}{l}58 \\
58 \\
58\end{array}$ & $\begin{array}{l}.773 \\
12.486 \\
9.279\end{array}$ & & & \\
\hline Total & $\begin{array}{l}\text { writing } \\
\text { CT } \\
\text { vcb }\end{array}$ & $\begin{array}{l}1822.500 \\
738875.000 \\
69971.000\end{array}$ & $\begin{array}{l}60 \\
60 \\
60\end{array}$ & & & & \\
\hline Corrected Total & $\begin{array}{l}\text { writing } \\
\mathrm{CT} \\
\mathrm{vcb}\end{array}$ & $\begin{array}{l}126.483 \\
24924.583 \\
1762.183\end{array}$ & 59 & & & & \\
\hline
\end{tabular}

As displayed in the above table, all the sig values for grouping belonging to the three dependent variables scores turned out to be less than .05. Therefore, it is concluded that the experimental group significantly outperformed the control group in all the three posttests. As such, the three null hypotheses are rejected, meaning that reflective writing instruction significantly improved the learners' writing achievement, critical thinking and vocabulary achievement.

The following graphs visually inspect the mean differences of the two groups in each of the dependent variables: 


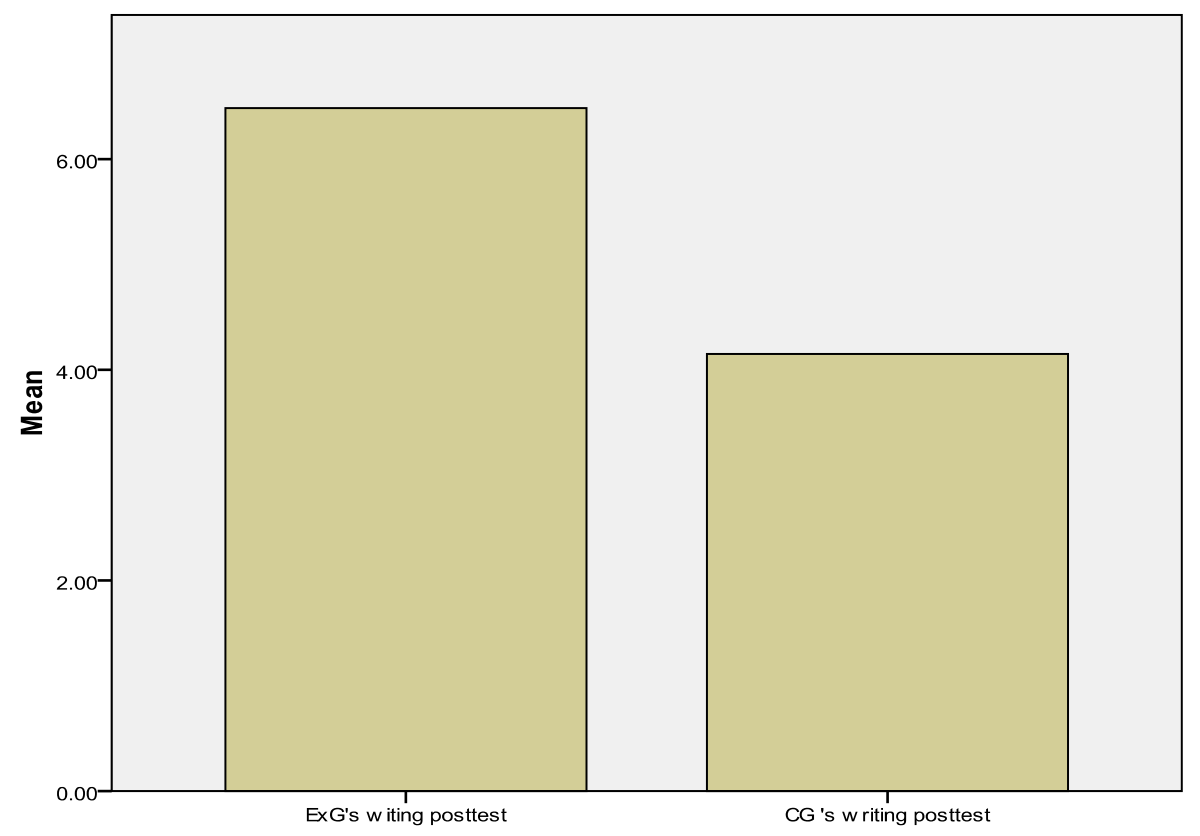

Figure 7. Bar graph representing the two groups' writing posttest mean scores

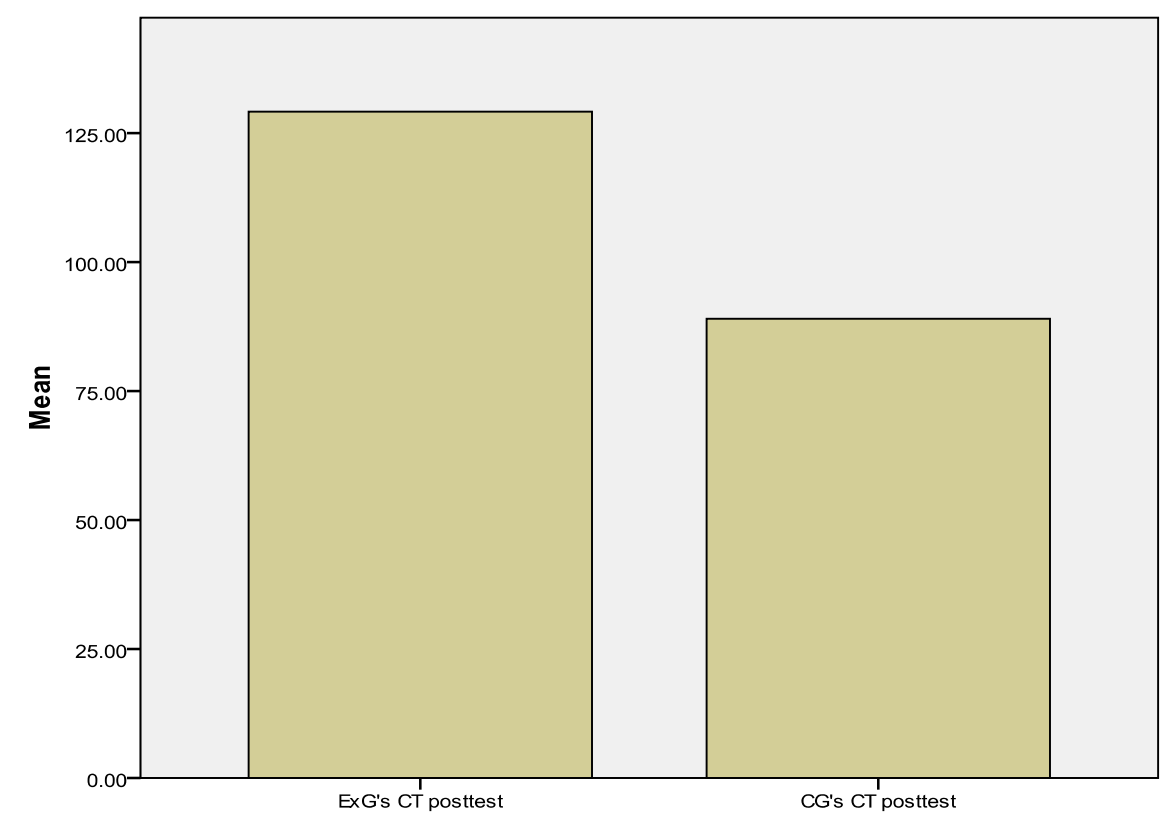

Figure 8. Bar graph representing the two groups' CT posttest mean scores 


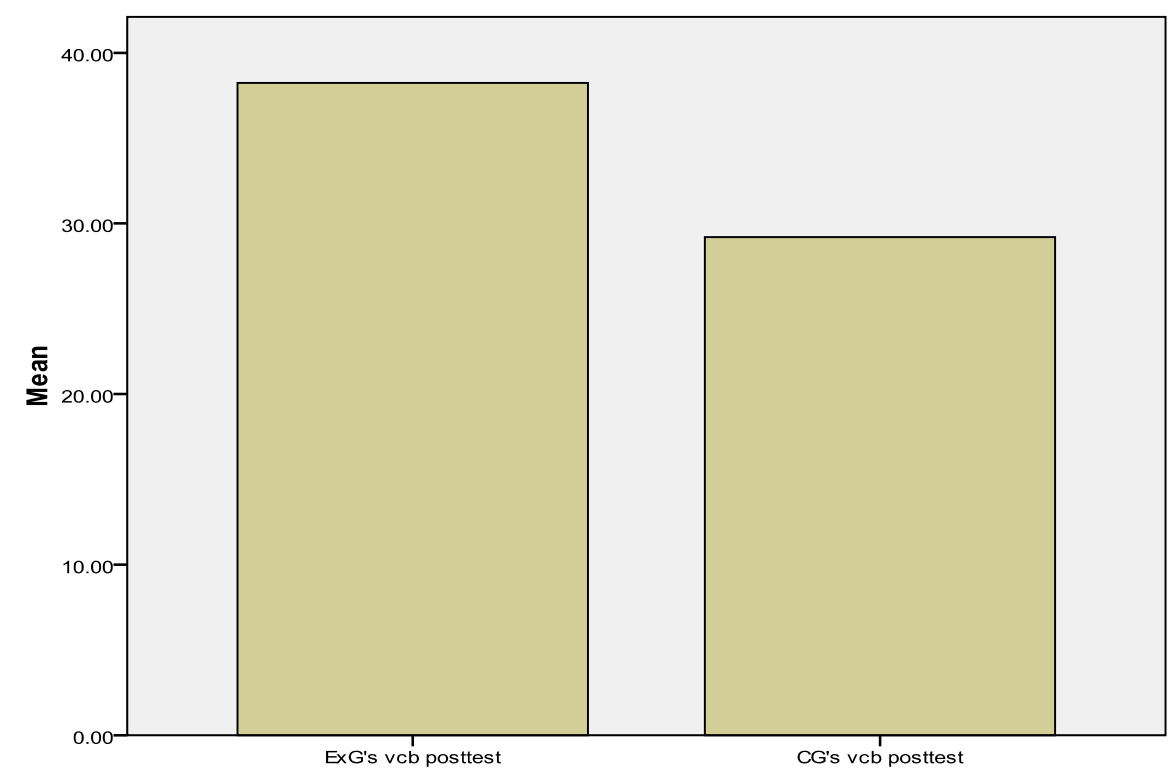

Figure 9. Bar graph representing the two groups' vcb posttest mean scores

\section{Discussion}

In this study, the impact of reflective writing on writing achievement, vocabulary achievement and critical thinking was shown to be significantly positive. Regarding the related literature the results and findings of the study are discussed in this part.

Given the fact that the participants of the two groups did not have any familiarity with the selected vocabulary, and were homogeneous regarding their writing ability and critical thinking skill but at the end of the treatment course the experimental group receiving reflective writing outperformed the control group on the three dependent variables, it can be concluded that the treatment, reflective writing had a positive impact on the learners' vocabulary achievement, writing achievement and critical thinking ability.

Reflective writing is an occasional requirement or it may be core feature of most or all assignments. "Reflection is indicative of deep learning, and where teaching and learning activities such as reflection are missing... only surface learning can result." (Biggs 1999 in King 2002).

The results of Branch and Paranjape study(Branch \& Paranjape, 2002, p. 1187) which compared the reflective writing between a group of students that wrote reflectively and a second group that wrote non-reflectively at the university revealed that the group who wrote reflectively made better improvement in vocabulary and critical thinking. Overall using reflective writing accounts can give learners opportunities to have better concentration on new vocabularies and the text and it can encourage them to have new insight to vocabulary learning and reflective writing.

Reflective writing helps students clarify their thoughts; work out strategies for solving problems; understand important aspects of their course; and identify areas where they need more help (Biggs 1999 in King 2002). "Reflection leads to growth of the individual - morally, 
personally, psychologically, and emotionally, as well as cognitively". (Branch \& Paranjape, 2002, p. 1187). Therefore using reflective writing can be beneficial in various dimensions to English language learners. According to Branch and Paranjape (Branch \& Paranjape, 2002, p. 1187), this process leads to critical thinking. Focusing on point of view in literature enlarges students' vision and fosters critical thinking. So, reflective writing can enhance students' writing achievement, vocabulary achievement and CT and the researcher could observe that in the treatment course and the outcome of the data analyses.

\section{Conclusion}

This study focused on the possible impact of reflective writing on writing achievement, vocabulary achievement and critical thinking of Iranian EFL learners. The result of the study showed that there was significant impact of reflective writing on EFL learners' writing achievement, vocabulary achievement and critical thinking.

Looking back at the literature, one would notice the issue that voluminous research studies have been implemented on the use of reflective writing and the effect of reflective writing on acquiring language skills. For example in a study on the effect of reflective writing on the acquisition of English language skills, Branch and Paranjape (2002) came to the conclusion that reflective writing as a chance to develop and reinforce skills, specially writing skill was considerably effective in improving subjects' acquiring the foreign language skills.

Reflective writing is a process where one can learn from their experiences. It can help to become more aware of assumptions and preconceived ideas.

\section{References}

Alfaro-LeFevre, R. (1995). Critical thinking in nursing: A practical approach. Philadelphia: W. B. Saunders.

ALLEN, Virginia French. Techniques in Teaching vocabulary: Teaching techniques in English as a second or foreign language. New York: Oxford University Press, 1983. ISBN 0-19-434130-5

Anson, C.M. (2002). The wac casebook. New York: Oxford University Press.

Applebee, A.N. \& Langer, J.A. (2006). The state of writing instruction in america's schools: what existing data tells us. Retrieved May 05, 2007, from http://cela.albany.edu

Astleitner, H. (2001). Teaching critical thinking online. Journal of Instructional Psychology, 29(2), 53-76.

Atwell, N. (1998). Learning how to teach reading. In L. Bridges (Ed.), In the middle: New understandings about writing, reading, and learning (pp. 29- 41). Portsmouth, NH: Boynton/Cook.

Bailin, S., Case, R., Cooms, J.R., \& Daniels, L.B. (1999). Common misconceptions of critical thinking. Journal of Curriculum Studies, 31(3), 269-283. http://dx.doi.org/10.1080/002202799183124 
Bloom, B. (1964). Taxonomy of Educational Objectives: Handbook 1: Cognitive Domain. Longman.

Bolton G. (2001). Reflective Practice: Writing and Professional Development. London: Paul Chapman Publishers.

Brookfield, S.D. (1987). Developing critical thinkers. San Francisco: Jossey-Bass Publishers.

Brookfield, S. (1987). Developing critical thinkers: challenging adults to explore alternative ways of thinking and acting, Open University Press, Milton Keynes.

Bromley, K. (1999). Key components of sound writing instruction. In Gambrell, L.B., Morrow, L.M., Neuman, S.B., \& Pressley, M. (Ed.), Best practices in literacy instruction. (pp.152-174). New York, NY: The Guilford Press.

Burton, J. (2007). Writing as a teacher education tool (unpublished paper based on keynote conference paper presented at Th aiTESOL, Chiang Mai, January 2006).

Carstairs-MacCarthy, A. (2002). An introduction to English Morphology. Edinburg: Edinburg University Press.

Center for Critical Thinking (2003). www.CriticalThinking.org.

Chaffee, J. (2006). Thinking critically. Boston: Houghton Mifflin.

Collins, J.L. \& Lee, J. (2005). Bringing together reading and writing for the purpose of enhancing reading comprehension. Retrieved July 3, 2006, from http://www.gse.buffalo.edu/ePortfolio/doc.aspx?ID=1887

Daniels, H., Hyde, A., \& Zemelman, S. (1998). Best practice in reading \& Best practice in writing. In W. Varner (Ed.), Best practice: New standards for teaching and learning in america's schools. (pp. 24-82). Portsmouth, NH: Heinemann.

Decarrico, J. s. (2001). Vocabulary learning and teaching. In M. Celce- Murcia (Ed.) teaching English as a second or foreign language ( $3^{\text {rd }}$ ed.) (pp.285-299). Boston: heinle \&Heinle.

Dewey, J. (1933). How we think: A restatement of the relation of reflective thinking to the educative process. Boston: D.C. Heath.

Ellison G. Reflective Writing in Medical Education. www.gailellison.com.

Ellis, N. (1995). The psychology of foreign language vocabulary acquisition: Implications for CALL. Computer Assisted Language Learning, 8, 103-128. http://dx.doi.org/10.1080/0958822940080202

Ellis, N. (2001). Vocabulary acquisition: Word structure, collocation, word class, and meaning. In N. Schmitt and M. McCarthy (Eds.), Vocabulary: Description, acquisition, and pedagogy (pp.122-139) Cambridge: Cambridge UniversityPress. 


\section{Macrothink}

Journal of Studies in Education

ISSN 2162-6952

2015, Vol. 5, No. 3

Empire State College. (2007). Informal writing: Uses. Retrieved June 02, 2007, from http://www.esc.edu/esconline/across_esc/writerscomplex.nsf/0/89705c80e7116fb6852569c30 074c5b8?OpenDocument

Ennis, R. H. (1987). A taxonomy of critical thinking dispositions and abilities. In J. Baron \& R.

Ennis, R. H. (1991). Goals for a critical thinking curriculum. In A. L. Costa (Ed.), Developing minds: A resource book for teaching thinking (pp. 68-71). Virginia: Association for Supervision and Curriculum Development.

Ennis, R. H. (1992). Assessing higher order thinking. In J. Keefe \& H. Walberg (Eds.), Teaching for thinking (pp. 45-67). Reston, VA: NASSP.

Facione, P.A. (1990). Critical thinking: A statement of expert consensus for purposes of educational assessment and instruction. Research findings and 247 recommendations. Newark, DE: American Philosophical Association. (ERIC Document Reproduction Service No. ED315423)

Fahim, M., Erfanrad, S.(2012). Developing critical thinking Iranian EFL students' argumentative essay through Shor's problem- posing pedagogy. Iranian EFL Journal. Vol.8, Issue4.

Fisher, D., Frey, N., \& Williams, D. (2002). Seven literacy strategies that work. Educational Leadership, 60(3), 70-73.

Fitzpatrick, K. (1993). Improving reading comprehension using critical thinking strategies. Reading Improvement, 31, 142-144.

Fulwiler, T. (1986). The argument for writing across the curriculum. In A. Young \& T. Fulwiler (Ed.), Writing across the disciplines: Research into practice (pp.21-32). Upper Montclair, NJ: Boynton/Cook Publishers, INC.

Gass, S. (1999). Discussion: Incidental vocabulary learning. Second language reading and vocabulary learning, 21, 319-333. http://dx.doi.org/10.1017/s0272263199002090

Gibbs, G. Rust, C. Jenkins, A. Jaques, D. 1994, Developing Students’ Transferable Skills. Oxford Centre for Staff Development.

Glaser, E. M. (1941). An experiment in the development of critical thinking. NewYork: Teachers' College of Columbia University Bureau of Publications,4-6.

Glock, N. C. (1987). Public policy and educational reform. Paper presented at the 1987 Fall Conference of the Academic Senate of the California Community College, Los Angeles.

Gorgian, B., Pazhakh, A., Parang, K.(2012). an investigation of the effect of critical thinking $(\mathrm{CT})$ instructions on Iranian EFL learners' descriptive writing: a case of gender study. Advances in Asian Social Sciences. Vol.1, No.1. 
Graves, M.F., Juel, C., \& Graves, B.B. (1998). Teaching reading in the 21 st century. Boston: Allyn and Bacon.

Halpern, D. (1997). Critical thinking across curriculum: A brief edition of thought and knowledge. Mahwah, NJ: Lawrence Erlbaum.

Halpern, D. (1999). Teaching for critical thinking: Helping college students develop the skills and dispositions of critical thinking. In R. E. Young (Ed.), New Directions for Teaching and Learning, no. 80. San Francisco:Jossey-Bass. http://dx.doi.org/10.1002/t1.8005

HARMER, Jeremy. The Practice of English Language Teaching. Essex: Longman Group UK Limited, 1993. ISBN 0582-04656-4

Jones, E.A., Hoffman, S., Moore, L.M., Ratcliff, G., Tibbetts, S., \& Click, B.A. (1995). National assessment of college student learning: Identifying college graduates' essential skills in writing, speech and listening, and critical thinking (NCES 95-001). Washington, DC: U.S. Government Printing Office.

Kataoka-Yahiro, M. (1994). A critical thinking model for nursing judgement. Journal of Nursing Education, 33, 351-356.

Kelly, M. O. (2003). An examination of the critical and creative thinking dispositions of teacher education students at the practicum point. Unpublished doctoral dissertation. University of Massachusetts Boston, Massachusetts.

Knoeller, C. (2003, May). Imaginative response: teaching literature through creative writing. English Journal, 92(5), 42-44. http://dx.doi.org/10.2307/3650423

Krashen, S. (1989). We acquire vocabulary and spelling by reading: Additional evidence for the input hypothesis. The Modern Language Journal, 73, 440-464. http://dx.doi.org/10.1111/j.1540-4781.1989.tb05325.x

Kurfiss, J. G. (1989). Critical thinking: Theory, research, practice, and possibilities, ASHE ERIC Higher Education Report No. 2, Washington, DC: Association for the Study of Higher Education.

Langer, J.A. (1992). Speaking of knowing: Conceptions of understanding in academic disciplines. In A. Herrington \& C. Moran (Ed.), Writing, teaching, and learning in the disciplines (pp.69-85). New York, NY: The Modern Language Association of America.

Laufer, B. (1997). The lexical plight in second language reading. Cambridge: Cambridge University Press.

Layeghi, F. (2011). Format and content in the argumentative writing of extrovert and introvert Iranian EFL learners. Iranian EFL Journal. Vol. 7, Issue3 166-183. Lewis, A. \& Smith, D. (1993). Defining higher order thinking. Theory into Practice, 32 (3), 131-137.

Lipman, M. (1988). Critical thinking - What can it be? Educational Leadership, 46(1), $38-43$. 
Lipman, M. (1994). Thinking in education. Cambridge: Cambridge University.

McCARTHY, Michael. Vocabulary. Oxford: Oxford University Press, 1992. ISBN 019-437136-0

Maley, A. (1986). Series editors' preface. In J . Morgan, and m. Rinvolucri(Eds.), vocabulary. Oxford: Oxford university press.

Marashi, H., Jafari, R.(2012). The comparative effect of using critical thinking, constructivist learning, and combination of the two techniques on EFL learners' writing. Iranian EFL Journal, 8(4), 206-225.

Marzano, R. J., Brandt, R. S., Hughes, C. S., Jones, B. F., Presseisen, B. Z., Rankin, S. C., \& Suhor, C. (1991). Dimensions of thinking: A framework for curriculum and instruction. In A. L. Costa (Ed.), Developing minds: A resource book for teaching thinking (pp.89-93). Alexandria, Virginia: Association for Supervision and Curriculum Development.

Maughan, C., and Webb, J. (2001).Small group learning and assessment. Retrieved August 01, 2007, from the higher Education Academy website:www.uukcle.ac.uk/resources /tempt/assessment.hhtml

McPeck, J. (1981). Critical thinking and education. New York: St. Martin's Press.

Meara, p. (1982). Vocabulary acquisition: A neglected aspect of language learning. Language Teaching and Linguistics, 13(4): 221-246.

Meara, p. (1982). Vocabulary acquisition: A neglected aspect of language learning. In. V. Kinsella(Eds.), Cambridge language teaching surveys, (p. 100-126). Cambridge University Press

Meyers, C. (1986). Teaching students to think critically. San Francisco: Jossey-Bass.

Mezirow, J 1990, Fostering critical reflection in adulthood: a guide to transformative and emancipatory learning, Jossey-Bass, San Francisco.

Moon, J, 1999, Learning Journals: A Handbook for Academics, Students and Professional Development. Kogan Page

Nation, I.S.P. (2001). Learning vocabulary in another language. Cambridge: Cambridge University Press. http://dx.doi.org/10.1017/CBO9781139524759

Nation, I. S. P. \& Waring, R. (2001). Vocabulary size, text, text coverage and word lists. In N. Schmitt and M. McCarthy (Eds.), Vocabulary: Description, acquisition, and pedagogy (pp.6-19). Cambridge: Cambridge University Press.

Nation, I. S. P. (1990). Teaching and learning vocabulary. New York: Newberry House.

Nation, I. S. P., \& Waring, R. (1997). Vocabulary size, text coverage and word lists. In N. Schmitt \& M. MaCarthy (Eds.), Vocabulary: Description, acquisition, andpedagogy (pp. 6-19). Cambridge: Cambridge University Press. 


\section{Macrothink}

Journal of Studies in Education

ISSN 2162-6952

2015, Vol. 5, No. 3

Nation, P. (2001). Learning vocabulary in another language. Cambridge: Cambridge122 University Press. http://dx.doi.org/10.1017/CBO9781139524759

Paul, R. (1995). Critical thinking: How to prepare students for a rapidly changing world. Santa Rose: Foundation for Critical Thinking.

Paul, R., \& Elder, L.(2008). Defining critical thinking, Retrieved September 22, 2009, from http://www.criticalthinking.org/DefiningCriticalThinking.html.

Pithers, R. T. \& Soden, R. (2000). Critical thinking in education: A review. Educational Research, 42, 237-249. http://dx.doi.org/10.1080/001318800440579

Read, J. (2000). Assessing vocabulary. Cambridge: Cambridge University Press. http://dx.doi.org/10.1017/CBO9780511732942

River, W. M. (1981). Foreign language skills. Chicago: University of Chicago Press.

Roy R. (2007). Teaching cultural sensitivity through literature and reflective writing. Virtual Mentor, 9(8), 543-546. http://dx.doi.org/10.1001/virtualmentor.2007.9.8.medu1-0708

Russell, D.R. (1992). American origins of the writing-across-the-curriculum movement. In A. Herrington \& C. Moran (Ed.), Writing, teaching, and learning in the disciplines (pp.22-42). New York, NY: The Modern Language Association ofAmerica.

Schmitt, N. \& Schmitt, D. (1995). Vocabulary notebooks: Theoretical underpinnings and practical suggestions. ELT Journal, 49,133-143. http://dx.doi.org/10.1093/elt/49.2.133

Schmitt, N. (2002).Vocabulary in language teaching. Cambridge: Cambridge University Press.

Schmitt, N., \& McCarthy, M. (Eds.) (1997). Vocabulary: Description, acquisition and pedagogy. Cambridge: Cambridge University Press.

Schmitt, N. (2000). Vocabulary in language teaching. Cambridge: Cambridge University Press.

Sezer, R. (2008). Integration of critical thinking skills into elementary school teacher education courses in mathematics. Education, 128(3), 349-362.

Shangarffam, N., Mamipour, M.(2011). The impact of teaching of critical thinking on intermediate EFL learners' writing skill. American Journal of Scientific Research ISSN1450-223XIssue 40.

Shapiro J, Kasman D, \& Shafer A. (2006). Words and wards: a model of reflective writing and its uses in medical education. $J$ Med Humanit., 227, 231-244. http://dx.doi.org/10.1007/s10912-006-9020-y

Siegel, H. (1988). Educating reason: Rationality, critical thinking and education.London: Routledge. Spotlight 26, The Scottish Council for Research in Education. Retrieved on March 12, 2007, from http://www.scre.ac.uk/pdf/spotlight/Spotlight26. pdf. 


\section{Macrothink}

Journal of Studies in Education

ISSN 2162-6952 2015, Vol. 5, No. 3

Siegel, M. \& Carey, R.F. (1989). Critical thinking: A semiotic perspective. Bloomington: Smith Research Center.Special Connections. (2007). An introduction to writing. Retrieved June $\quad$ 2, 2007, from http://www.specialconnections.ku.edu/cgibin/ cgiwrap/specconn/main.php?cat=instruction\&subsection=writing/main

Stankato, F. A. (2000). Tenure, academic freedom, and the teaching of critical thinking. College Student Journal, 34(3), 377-383. Sternberg (Eds.), Teaching thinking skills: Theory and Practice (pp. 9-26). New York: W. H. Freeman.

THORNBURY, Scott. (2004). How to Teach Vocabulary. Essex: Pearson Education Limited, ISBN 0582-429668

UR, Penny. (2000). A Course in Language Teaching: Practice and theory. Cambridge: Cambridge University Press, ISBN-0521-44994-4

Walkner, P., \& Finney, N. (1999). Skill development and critical thinking in higher education. Teaching in Higher Education, 4(4), 531-548. http://dx.doi.org/10.1080/1356251990040409

Zemelman, S., Daniels, H., \& Hyde, A. (1998). Best practice: New standards for teaching and learning in america's schools. Portsmouth: Heinemann. 